The Agricultural Revolution in South Lincolnshire demonstrates painstaking research, mastery of English (though 'number' is a singular noun: Dr. Grigg uses it as plural) and an inclusive grasp of the different factors that affect the agricultural economy of a region.

South Lincolnshire is divided sharply by categories of soil, and slight but marked changes in elevation though little of it is above the $500-\mathrm{ft}$. level. From the coast to the Heath there are the marsh and the fen, divided into two parts, the silts and the peats, covering nearly half the area; then a low plain; then the Heath, beyond which the land declines again to the basins of the rivers Witham and Brant. The soils and the lack of efficient drainage and flood control made the task of the farmer one of great difficulty in the late eighteenth contury, in spite of the long work of centuries on the rivers and flood areas. These natural impediments were not eased by the system of land holding, many acres of open fields being rotained until the 1790 's. Flood waters, too, restricted agricultural activities, some areas being known as 'half-year lands' because they could not be safely used for crops sown in autumn. Dr. Grigg has come to the conclusion that during the French Wars South Lincolnshire farming was "essentially extensive and technologically backward". Perhaps so ! Nevertheless, numerous and varied crops were grown on the drior fen and marsh, and the four-course rotation had been adopted, to some extent, on the Wolds and Heath by about 1790 .

After victory in war at Waterloo, and even a year or so before, there was a drop in prices which hit farmers pretty hard. Many took the facile line of reducing production cost by neglecting drainage, reducing cultivations, economizing by letting land fall down, and so on. Tho South Lincolnshire farmers took the opposite line. They intensified their farming, introduced more fodder crops, roots and clover, where the soil was suitable, and generally adopted mixed farming, the most advanced system of the time. Betwoen 1815 and 1850 this area, with suitable variations in the different geographical regions, became an example of how to meet financial handicaps by adopting a more intensive system giving a higher yield of crops and producing better breeds of livestock. Incidentally, the new methods made a greater demand for labour so that the whole system was more expensive although it was very much more productive. Dr. Grigg has collected evidence that seems to show that the average yield of wheat in South Lincolnshire was between 28 and 32 bushels an acre round 1850 . 'This is very high and equal to the national average between the two World Wars. The sheep and cattle, too, were by then of outstanding quality. No significant change in the size of farms seems to have taken place during this period of development.

It remains to be seen whether other farmers in other districts recovered their financial stability by reason of adopting this risky and drastie procedure, or whether the recovery' that took place by 1850 , and lasted to the 1870 's, was caused by general circumstances outside the farmer's control. I tend to the latter opinion, but the point is not yet alear. Meanwhile, Dr. Grigg's work deserves the closest attention, not only because it presents a novel but well-substantiated point of view, but also because it is an excellent example of how such studies should be carried out.

G. E. Fusseit

\section{PHYSIOLOGY OF VISION}

Vision and Visual Perception

Edited by Prof. Clarence H. Graham. Pp. vii +637 . (New York and London: John Wiley and Sons, Ine., 1965.) $180 s$.

HE number of experimental psychologists to have
made notable contributions to the physiology of in the United States. Six of them have clubbed together and, encouraged by Clarence Graham, have produced the best book on visuology since Helmholtz. The comparison may seem unfair because Helmholtz did it all on his own and Vision and Visual Perception is a smaller volume, contributed to by six workers. However, the six had more to chew, digested it well, and the balance seems just about right: no man could be expected to deal authoritatively with all the ramifications of this bewildering topic and too many writers might have wrecked the script.

The contents are orthodox. By way of prolegomenon, we are treated to a description of the nature of light, photometry, basic optics, and-most welcome of all-to an account of how to set up the sort of apparatus used by the authors and many of those whose work they discuss. The outline of the structure of the visual system is helpful, although a comparison of Figs. $2 \cdot 5$ and $2 \cdot 6$ is irritating, and the description of the crystalline lens and its function outdated. To say categorically that there is no evidence of binocular fusion within layers of the lateral geniculate body is an admission of ignorance of the work of Bishop and his collaborators. The electrophysiology of vision is dealt with competently and fairly, but as is inevitable in the tornado of data production that has built up-is beginning to assume the patina of history. The account of cortical activity is a masterpiece of assimilation and more useful than the more pretentious offerings of many an earlier author. But it is sad to have to report, that the poor quality of the chapter on photochemistry is not due solely to the contrast it unfortunately offers to the rest of the book. The writer of this chapter has no 'feel' for the subject. There is nothing presumptive about difference spectra being unaffected by light-insensitive impurities, and the opinion that they consist of two portions is like saying that my overdraft consists of two parts: the money I owe to my bank and the money it is owed by me. The endless data on thresholds are well presented, and it is interesting to learn that frequency-ofseeing curves were used nearly 40 years ago. Brightness discrimination and contrast are related to electrophysio. logical data, and the modulation aspect of flicker is brought out with great clarity. However, the comparison of electro-retinographic fusion curves as obtained for cats, guinea-pigs, and pigeons (Fig. 10.15) would have gained in significance with an attempt to relate the stimulus to the retina, not to say the receptor types involved.

Visual acuity is discussed by a master although the omission of any reference to the transfer function of the eye is the most surprising gap to be found in the book: when was this chapter written? Colour vision is covered in five excellent chapters leaning perhaps a little heavily on concepts not readily subscribed to by physicists and physiologists, yet competent, searching, and fair. Vociferous authors, adulated by less critical writers, are dismissed irreverently though with justice. The discussion of the convergence of confusion loci leaves something to be desired, especially as it is going to be of decisive import in our acceptance or rejection of recent data on cone pigments. While the detailed treatment of the lineelement is welcome, the account of Hecht's theory and the repetition of Laurens and Hamilton's data are surely prompted by feelings of piety. Contrast and related subjects, and after-images, have nover been discussed in such detail and with such a sure touch. Again, the chapters on binocular vision, and perception of form and movement, while brief, are free from the noise of grinding axes.

Text-books are becoming more and more expensive and all but pricing themselves out of the student's wallet. However, this book is a must. It puts in the shade much of what went before and, if statistics is anything to go by, what the near future is going to bring.

R. A. WEALE 